\title{
PENGARUH MOTIVASI KERJA ISLAM DAN BUDAYA KERJA ISLAM TERHADAP PRODUKTIFITAS KERJA KARYAWAN BMT DI GERBANGKERTASUSILA
}

\author{
Achmad Nur Iman \\ Departemen Ekonomi Syariah-Fakultas Ekonomi dan Bisnis-Universitas Airlangga \\ Email: achmadiman10@gmail.com \\ Ari Prasetyo \\ Departemen Ekonomi Syariah-Fakultas Ekonomi dan Bisnis-Universitas Airlangga \\ Email: ari.prasetyo@feb.unair.ac.id
}

\begin{abstract}
:
This study attempts to know the importance of perception employees of Islamic work motivation and Islamic work culture to employees' productivity whether partial and simultaneous on the quality of performance of BMT employees in the area of gerbang kertasusila in East Java. The study population that is used in this study is all of BMT employees taken by random as many as 200 respondents. The analysis technique used is multiple linear regression. The research results showed that simultaneously being tested use test $F$ shows that there has been a significant impact between independent and dependent variables. While in partial being tested, use T-test indicate that the presence of variables of Islamic work motivation and Islamic work culture on employees' productivity of BMT had a positive and significant impact and some influential negative to productivity performance office BMT in the area of gerbangkertasusila in East Java.
\end{abstract}

Keywords: Baitul mal wat tamwil, Islamic work motivation, Islamic work culture, employees' productivity.

\section{PENDAHULUAN}

Di Indonesia bekerja masih dianggap sebagai sesuatu yang rutin. Bahkan pada sebagai karyawan, bisa jadi bekerja dianggap sebagai beban dan paksaan terutama bagi orang yang malas. Pemahaman karyawan tentang budaya kerja produktif masih lemah.

Menurut Ninin (2007) rendahnya produktivitas kerja di Indonesia Karena kualitas SDM yang tidak mampu bersaing, mutu pendidikan rendah, kurikulum pendidikan tidak sesuai dengan kebutuhan pasar kerja, fasilitas Balai Latihan Kerja tidak optimal, dan perhatian pemerintah daerah rendah. Rendahnya produktivitas juga disebabkan minimnya penghargaan dan intensif bagi pekerja yang memiliki prestasi.

Budaya kerja produktif sama halnya dengan budaya kerja yang Islami, karena sesungguhnya budaya kerja Islami adalah budaya kerja yang mengutamakan produktivitas dengan memakai nilai-nilai Islam. Kurangnya pemahaman karyawan terhadap budaya kerja yang memakai nilai Islam menyebabkan kurang mendukung terciptanya budaya kerja produktif.

Pembentukan sikap mental karyawan dan pengusaha yang memiliki semangat kerja yang tinggi dalam suasana yang serasi, selaras, serta seimbang antara para karyawan. Dalam hubungan itu, maka untuk menjalin

1) Jurnal ini merupakan bagian dari skripsi Achmad Nur Iman, NIM: 041211432022, yang diuji pada 21 Januari 2019. 
Iman, et al/Jurnal Ekonomi Syariah Teori dan Terapan Vol. 6 No. 1 Januari 2019: 170-187; PENGARUH MOTIVASI KERJA ISLAM DAN BUDAYA KERJA ISLAM TERHADAP PRODUKTIFITAS KERJA KARYAWAN BMT DI GERBANGKERTASUSILA

kerjasama yang lebih serasi antara karyawan dan pengusaha, masingmasing pihak perlu meningkatkan rasa tanggung jawab, rasa ikut memiliki dan keberanian mawas diri dalam rangka kelangsungan hidup organisasi.

$$
\text { Hadirnya BMT sekarang ini }
$$

merupakan fenomena baru, yang merupakan upaya untuk memenuhi kebutuhan umat Islam dalam jasa keuangan. Meskipun pada dasarnya tidak hanya dikhususkan pada umat Islam saja. Produk dan jasa yang diberikan dan direncanakan untuk masa depan tanpa memandang jenis agama dan keyakinan, harus didasarkan pada pertimbangan yang seksama secara cermat tentang kecenderungan dalam masyarakat di masa yang akan datang.

Perkembangan BMT di Jawa Timur yang dapat dilihat saat ini adalah semakin bertambahnya nasabah dan antusias masyarakat dengan ikut serta dalam mengembangkan lembaga kevangan syariah sebagai nasabah di karenakan BMT lembaga yang tidak mengutamakan profit semata tetapi lebih ke sejahteran masyarakat, hal ini dapat dilihat dari salah satu contoh perkembangan BMT di Indonesia khususnya di jawa timur seperti.

Dari data pada tabel dibawah ini dapat disimpulkan bahwa perkembangan BMT di Jawa Timur disetiap tahunnya terdapat peningkatan di setiap tahunnya hal ini dapat dilihat bahwa tabel perkembangan peminjam dari tahun 2004-2016 terdapat peningkatan dimana peminjam (nasabah) dari tahun 2004 dengan jumlah 111 nasabah meningkat signifikan sampai tahun 2016 dengan jumlah 24.687 nasabah. Sehingga terdapat peningkatan yang signifikan juga didalam perkembangan aset, modal dari tahun 2004 - 2016. Dan jika di lihat pada tabel modal/ekuitas., maka dari itu dapat disumpulkan bahwa perkembangan BMT di wilayah Jawa Timur dapat diartikan meningkat secara signifikan dan memiliki tingkat profitabilitas yang tinggi. Dari data inilah dapat dibuktikan bahwa perkembangan BMT di Jawa Timur berkembang pesat (Gambar 1.).

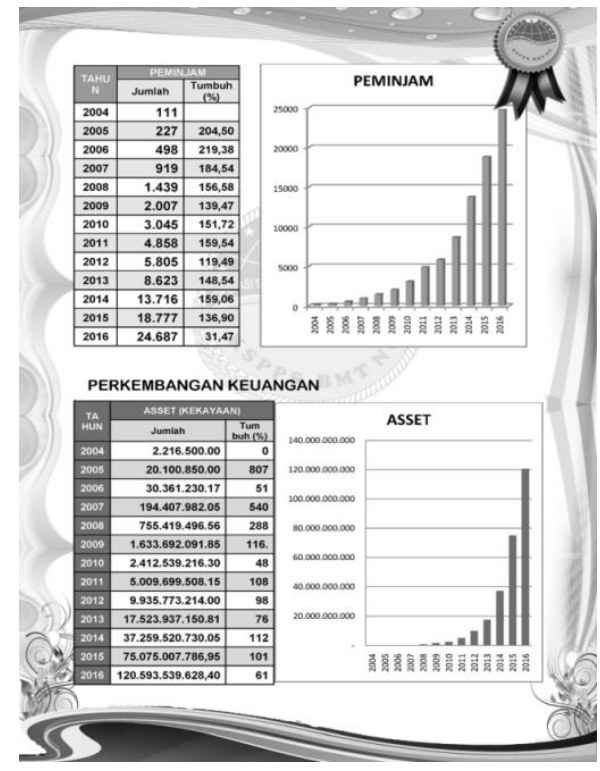

Sumber :data menteri Koperasi dan

UMKM, 2018

Gambar 1 Perkembangan Keuangan dan peminjaman BMT NU JAWA TIMUR SEJAK AWAL BERDIRI (2004) S.D. 2016 ( 13 TAHUN)

Berdasarkan pada latar belakang masalah di atas, maka dapat dirumuskan permasalahan penelitian sebagai berikut: 
1. Apakah motivasi kerja Islam berpengaruh terhadap produktivitas kerja karyawan BMT di wilayah Kota/kabupaten (Gerbangkertasusila)?

2. Apakah budaya kerja Islam berpengaruh terhadap produktivitas kerja karyawan BMT di wilayah Kota/kabupaten (Gerbangkertasusila)?

3. Apakah motivasi kerja dan budaya kerja Islam berpengaruh secara bersama-sama terhadap produktivitas kerja karyawan BMT di wilayah Kota/kabupaten (Gerbangkertasusila)?

Tujuan yang ingin dicapai dalam penelitian ini adalah :

1. Untuk mengetahui pengaruh motivasi kerja Islam terhadap produktivitas kerja karyawan BMT di wilayah Kota/kabupaten (Gerbangkertasusila).

2. Untuk mengetahui pengaruh Budaya Kerja Islam terhadap produktivitas kerja karyawan BMT di wilayah Kota/kabupaten (Gerbangkertasusila).

Untuk mengetahui pengaruh Motivasi kerja dan budaya kerja Islam secara bersama-sama terhadap produktivitas kerja karyawan BMT diwilayah Kota/kabupaten (Gerbangkertasusila) .

Berdasarkan tujuan yang hendak dicapai dalam penelitian ini, manfaat yang diharapkan adalah:

1. Secara Teoritis Dapat memberikan sumbangan pemikiran bagi pengembangan ilmu syariah pada umumnya dan keuangan Islam pada khususnya.
2. Secara praktis Bagi peneliti, penelitian ini dapat dijadikan acuan bagi karyawan BMT di Kota/kabupaten (Gerbangkertasusila). Secara pihak yang terkait di dalamnya dalam mengambil kebijakan, khususnya mengenai peningkatan produktivitas kerja karyawan.

\section{LANDASAN TEORI}

Dalam bukunya yang berjudul Bekerja dengan Hati Nurani, (Akh. Muwafik Saleh, tidak ada tahun ) mengatakan selama ini, banyak orang bekerja untuk mengajar materi belaka demi kepentingan duniawi, mereka tak sedikitpun memperdulikan kepentingan akhirat kelak. kepribadian yang baik dan dibenarkan oleh Islam yang harus memenuhi ciri-ciri sebagai berikut:

1. Niat Baik dan Benar (Mengharap Ridha Allah SWT) Sebelum seseorang bekerja, harus mengetahui apa niat dan motivasi dalam bekerja, niat inilah yang akan menentukan arah pekerjaan. Jika niat bekerja hanya untuk mendapatkan gaji, maka hanya itulah yang akan didapat.

2. Takwa Dalam Bekerja Takwa di sini terdapat dua pengertian. Pertama, taat melaksanakan perintah dan menjauhi segala bentuk laranganNya. Kedua, sikap tanggung jawab seorang muslim terhadap keimanan yang telah diyakini dan diikrarkannya.

Pada hakikatnya, Kerja adalah merupakan bentuk dari amal kebajikan. Islam memandang bekerja tidak hanya menyangkut 
mencari rezeki. Lebih luas dari itu, Berkaitan dengan amalan-amalan kebaikan untuk meraih keberkahan dan keridaan Allah Swt. Sebagai sebuah amal, maka niat dalam menjalankannya akan menentukan nilai suatu pekerjaanLandasan Menurut Badrul ( 2012) ikhtiar agar manusia bekerja sesuai norma dan etika yang Islami yaitu :

1. Hubungan individu dengan Allah : Adanya kesadaran bahwa Allah Swt melihat, mengetahui dan mengontrol seluruh kegiatan manusia..

2. Bekerja adalah ibadah : Bekerja dalam pandangan Islam begitu tinggi derajatnya. Sedemikian tingginya nilai bekerja, sehingga Allah dalam Al Qur'an menyamakannya dengan jihad. "Bekerja dengan cara yang halal : Bekerja wajib dilakukan dengan cara yang halal dan baik, pada semua jenis pekerjaan.Professionalisme : Bekerja harus memperhatikan profesionalisme, yaitu kemampuan untuk memahami dan melakukan pekerjaan sesuai dengan prinsipprinsip keahlian. Rasulullah Saw bersabda: "Jika amanat telah disiasiakan, tunggu saja kehancuran terjadi." Ada seorang sahabat bertanya; 'bagaimana maksud amanat disia-siakan? Nabi menjawab, "Jika urusan diserahkan bukan kepada ahlinya, maka tunggulah kehancuran itu." (HR. Bukharii).

Ramah terhadap lingkungan : Alam semesta ini, dengan segala isi yang terkandung di dalamnya, diciptakan oleh Allah Swt dengan memperhatikan hukumhukum kesetimbangan.

$$
\text { Para ekonom biasanya }
$$

mendefinisikan produktivitas sebagai

"ratio output" dibandingkan dengan "input fisik". Hal tersebut biasanya dihubungkan dengan industri-industri secara keseluruhan pada sektor-sektor dalam suatu perekonomian

Dari pengertian motivasi kerja Islam dan produktifitas diatas dapat ditarik kesimpulan bahwa Sumber Daya Manusia merupakan salah satu faktor yang dibutuhkan perusahaan untuk melaksanakan kegiatan atau aktivitas perusahaan guna mencapai tujuannya.

Persaingan mengakibatkan perusahaan-perusahaan dituntut untuk mampu bertahan dan semakin dapat memacu dirinya untuk berkembang, namun disisi lain tidak sedikit pula perusahaan-perusahaan yang jatuh karena tidak mampu bersaing dengan perusahaan lain.

\section{Hipotesis dan Model Analisis}

Berdasarkan latar belakang, rumusan masalah dan landasan teori yang telah dipaparkan, maka dalam penelitian ini dapat dirumuskan hipotesis, yaitu :

a. Ada pengaruh positif dan signifikan antara motivasi kerja Islam terhadap produktivitas karyawan. 
b. Ada pengaruh positif dan signifikan antara budaya kerja Islam terhadap produktivitas karyawan.

c. Ada pengaruh positif dan signifikan antara motivasi kerja Islam dan budaya kerja Islam terhadap produktivitas karyawan.

\section{METODE PENELITIAN}

Penelitian ini menggunakan paradigma positivist (Positivism Paradigm). Positivisme menekankan akan pentingnya mencari fakta dan penyebab dari gejalagejala sosial dengan kurang memperhatikan tingkah laku subyektif individu yang dapat dimasukkan dalam kategori tertentu, yang dari anggapan itu tampak bahwa positivisme melatar belakangi pendekatan kuantitatif. Dengan cara itu, suatu fenomena dapat dianalisis untuk kemudian ditemukan hubungan di antara variabel-variabel yang terlibat didalamnya. Hubungan tersebut adalah hubungan korelasi atau hubungan sebab akibat.

Berdasarkan paradigma yang digunakan, maka penelitian ini dilakukan dengan pendekatan kuantitatif. Pendekatan kuantitatif merupakan salah satu pendekatan yang bertujuan untuk mengembangkan pengetahuan melalui pengujian terhadap hipotesa yang diajukan, melakukan pengukuran dan observasi, serta menguji suatu teori (Creswell, 2003). Pada penelitian ini, untuk menemukan menjawab pertanyaan dan menguji hipotesis penelitian, dilakukan dengan metode survey dan mengumpulkan data yang dikuantitatifkan dan selanjutnya dianalisis dengan menggunakan uji statistik.

Model regresi linear berganda (multiple regression) dapat disebut sebagai model yang baik, jika model tersebut memenuhi kriteria BLUE (Best Linear Unbeased Estimator). Kriteria BLUE dipenuhi jika 5 (lima) uji asumsi klasik dipenuhi:

1. Normalitas

Melihat apakah nilai residual terdistribusi normal atau tidak. Model regresi yang baik memiliki nilai residual yang terdistribusi normal

2. Multikolonearitas

Melihat ada atau tidaknya korelasi yang tinggi antar variabel bebas dalam model regresi.

3. Heterokedastisitas

Melihat apakah terdapat ketidak samaan varians dari residual ke pengamatan yang lain

\section{Autokorelasi}

Melihat apakah terjadi korelasi antara suatu periode dengan periode sebelumnya

5. Linieritas

Melihat model yang dibangun memiliki hubungan linear atau tidak

Secara umum, penelitian ini bertujuan untuk menguji dan menjelaskan pengaruh Motivasi Kerja Islam, Budaya Kerja Islam terhadap Produktivitas Kerja. Dengan demikian, penelitian ini ingin menjelaskan keterkaitan hubungan dan pengaruh antar variabel atau konstruk. 
Iman, et al/Jurnal Ekonomi Syariah Teori dan Terapan Vol. 6 No. 1 Januari 2019: 170-187; PENGARUH MOTIVASI KERJA ISLAM DAN BUDAYA KERJA ISLAM TERHADAP PRODUKTIFITAS KERJA KARYAWAN BMT DI GERBANGKERTASUSILA

\section{Definisi Operasional}

\section{Motivasi Kerja Islam $\left(X_{1}\right)$}

1. Niat Baik dan Benar (Mengharap Ridha Allah SWT) Sebelum seseorang bekerja, harus mengetahui apa niat dan motivasi dalam bekerja, niat inilah yang akan menentukan arah pekerjaan. Jika niat bekerja hanya untuk mendapatkan gaji, maka hanya itulah yang akan didapat. Tetapi jika niat bekerja sekaligus untuk menambah simpanan akhirat, mendapat harta halal, serta menafkahi kelvarga, tentu akan mendapatkan sebagaimana yang diniatkan.

2. Takwa Dalam Bekerja Takwa di sini terdapat dua pengertian. Pertama, taat melaksanakan perintah dan menjauhi segala bentuk larangan-Nya. Kedua, sikap tanggung jawab seorang muslim terhadap keimananyang telah diyakini dan diikrarkannya. Orang yang bertakwa dalam bekerja adalah orang yang mampu bertanggung jawab terhadap segala tugas yang diamanahkan.

3. Ikhlas Dalam Bekerja Ikhlas adalah syarat kunci diterimanya amal perbuatan manusia disisi Allah SWT. Suatu kegiatan atau aktivitas termasuk kerja jika dilakukan dengan keikhlasan maka akan mendatangkan rahmat dari Allah SWT.

\section{Budaya Kerja Islam $\left(\mathrm{X}_{2}\right)$}

Budaya kerja Islam yang diukur dengan kuesioner yang menentukan fakta sebagai berikut:

1. Ash- Sholeh (Baik dan bermanfaat)

$2 . \quad$ Al-ltqon

(Kemantapan atau perfectness)
3. .Al- Ihsan (Melakukan yang Terbaik atau Lebih Baik Lagi)

4. Al- Mujahadah (Kerja Keras dan Optimal)

5. Tanafus dan Taawun (Berkompetisi dan Tolong Menolong)

6. Mencermati nilai waktu

7. Shiddiq berarti memiliki kejujuran dan selalu melandasi ucapan, keyakinan, serta perbuatan berdasarkan ajaran Islam.

8. Istiqomah, artinya konsisten dalam iman dan nilai-nilai yang baik meskipun menghadapi berbagai godaan dan tantangan.

9. Fathanah, berarti mengerti, memahami dan menghayati secara mendalam segala hal yang menjadi tugas dan kewajiban.

10. Amanah, berarti memiliki tanggung jawab dalam melaksanakan setiap tugas dan kewajiban.

11. Tabligh, berarti mengajak sekaligus memberi contoh kepada pihak lain untuk melaksanakan ketentuan-ketentuan ajaran Islam dalam kehidupan sehari-hari

Produktivitas Kerja Karyawan (Y)

1) Produktivitas diartikan sebagai kemampuan seperangkat sumber-sumber ekonomi untuk menghasilkan sesuatu.

2) Produktivitas adalah perbandingan antara pengorbanan (output) dengan penghasilan (input).

3) Produktivitas adalah suatu sikap mental yang selalu mempunyai pandangan bahwa mutu kehidupan hari ini haruslah 
Iman, et al/Jurnal Ekonomi Syariah Teori dan Terapan Vol. 6 No. 1 Januari 2019: 170-187; PENGARUH MOTIVASI KERJA ISLAM DAN BUDAYA KERJA ISLAM TERHADAP PRODUKTIFITAS KERJA KARYAWAN BMT DI GERBANGKERTASUSILA

lebih baik hari kemarin dan hari esok harus lebih baik dari hari ini.

\section{Teknik Analisis}

Teknik analisis yang digunakan adalah regresi linier berganda. Analisis linier berganda adalah analisis terhadap model regresi yang memiliki lebih dari satu variabel independen. Teknik analisis ini digunakan untuk menguji pengaruh motivasi kerja Islam dan budaya kerja Islam Terhadap produktifitas kerja karyawan BMT di gerbang kerta susila linier berganda adalah sebagai berikut :

$\boldsymbol{Y}=\boldsymbol{\alpha}+\boldsymbol{\beta}_{\mathbf{1}} \boldsymbol{X}_{1}+\boldsymbol{\beta}_{\mathbf{2}} \boldsymbol{X}_{2}+$ Keterangan :

$Y$ : Produktifitas Karyawa

a: Intercept/ konstanta

$\mathrm{X}_{1}$ : motifasi kerja islam

$\mathrm{X}_{2}$ : budaya kerja islam

Bi: Koefisien regresi $(i=1,2, \ldots 4)$

$\mu$ : error term

\section{Uji Instrumen Penelitian}

Paradigma yang dikembangkan peneliti dalam penelitian ini adalah postpositivisme intrepretif karena menitik beratkan pada peranan bahasa, interpretasi dan pemahaman (Ghozali, 2005). Paradigma ini memfokuskan pada sifat sosial dan berusaha memahami dari kerangka berfikir obyek yang sedang diteliti. Sifat social artinya focus pada arti individu dan kelompok persepsi manusia pada'realitas independent. Oleh karena itu tujuan dari pengembangan teori dalam paradigma ini adalah untuk menghasilkan deskripsi, pandanganpandangan dan penjelasan tentang implementasi kinerja BMT yang baik, sehingga peneliti mampu mengungkap interpretasi dan pemahaman (makna) dalam lingkungan sosial. Untuk dapat memahami makna dan penafsiran fenomena dan simbol interaksi di BMT, maka dibutuhkan keterlibatan dan penghayatan langsung peneliti terhadap subyek penelitian di lapangan, maka diperlukan instrumen penelitian (Guba dan Lincoln, 1981). Untuk mengumpulkan data penelitian, baik untuk variabel Motivasi Kerja, Budaya Kerja,maupun Produktivitas perusahaan, digunakan kuesioner dan wawancara terbuka.

\section{Uji Validitas}

Pengujian validitas dilakukan dengan cara mengkorelasikan skor masing-masing butir pertanyaan dengan skor total sebagai hasil penjumlahan semua skor butir pertanyaan dengan menggunakan teknik korelasi product moment. Untuk mengetahui apakah suatu butir pertanyaan sudah dianggap valid, maka akan dilihat nilai dari koefisien validitas dibandingkan dengan nilai cut off value. Interpretasi koefisien validitas dianggap valid apabila koefisien validitas $>0.30$ sehingga butir - butir tersebut dianggap sahih, sebaliknya jika di dapatkan koefisien validitas kurang dari $0.30 \quad(<0.30)$ maka butir - butir tersebut tidak valid.

Kuesioner yang diberikan pada responden melalui sejumlah pertanyaan yang telah disusun sesuai dengan instrumen penelitian. Instrumen penelitian yang digunakan untuk pengumpulan data dalam penelitian ini adalah kuesioner yang disusun menggunakan 
Iman, et al/Jurnal Ekonomi Syariah Teori dan Terapan Vol. 6 No. 1 Januari 2019: 170-187; PENGARUH MOTIVASI KERJA ISLAM DAN BUDAYA KERJA ISLAM TERHADAP PRODUKTIFITAS KERJA KARYAWAN BMT DI GERBANGKERTASUSILA

5(lima) skala Likert, melalui lima alternatif jawaban, yaitu (4) Sangat Setuju; (3) Setuju; (2). Tidak Setuju (1). Sangat Tidak Setuju. Untuk mengetahui apakah instrumen penelitian mampu mengukur secara tepat dan cermat serta konsisten, maka akan dilakukan uji validitas dan reliabilitas instrumen penelitian. Disamping pengumpulan data melalui penyebaran kuesioner juga dilakukan wawancara dengan karyawan dan manajemen perusahaan BMT, dengan tujuan menggali informasi, memahami pendapat karyawan dan pemimpin, menganalisis dan memberi usulan pemikiran tentang berbagai hal terkait dengan BMT. proses penelitian ini memang menggunakan karyawan dan pemilik/manajemen/pimpinan yang sangat membantu dalam memahami aspek dalam pengelolaan perusahaan BMT termasuk menggali "yang tersirat dibalik tersurat". Dengan banyaknya informasi yang diperoleh diharapkan dapat digunakan sebagai usulan pemikiran-usulan pemikiran masukan kepada perusahaan.

\section{Uji Reliabilitas}

uji reliabilitas bertujuan untuk mengukur ukuran internal consistency indikator suatu variabel. Suatu kuesioner dapat dikatakan reliabel atau handal jika jawaban seseorang terhadap pertanyaan adalah konsisten atau stabil (Gozhali, 2005). Instrumen penelitian dikatakan reliabel jika nilai Cronbach Alpha > 0,60 ( Gozhali 2005).
Sebelum kuesioner disebarkan, terlebih dahulu akan dilakukan uji coba (trial) kepada 30 responden. Dalam uji coba ini, responden penelitian diambil dari BMT yang berada di Kota Surabaya. Dasar pemilihan BMT untuk uji coba kuesioner adalah adanya kesamaan karakteristik dari responden yang akan dianalisis.

\section{Uji Normalitas}

pengujian untuk mengetahui apakah data atau variabel yang dipakai terdistribusi secara normal. Apabila variabel yang dipakai terdistribusi secara normal, penelitian dapat dilanjutkan. Dengan nilai hasil test normalitas lebih dari $0,05(p>0,05)$ bisa dikatakan normal.

\subsubsection{Uji † (Uji Parsial)}

Adalah uji yang di gunakan untuk menyatakan signifikan pengaruh variabel bebas secara parsial terhadap variabel terikat, langkah-langkah:

1. Menentukan hipotesis nihil dan alternatif.

$\mathrm{HO}: \beta 1=\beta 2=0$ (tidak ada pengaruh yang signifikan antara motivasi kerja Islam dan budaya kerja Islam terhadap produktivitas kerja).

$\mathrm{HO}$ : $\beta 1$ ß 20 (ada pengaruh yang signifikan antara motivasi kerja Islam dan budaya kerja Islam terhadap produktivitas kerja).

2. Menentukan level of significant $/ O ́=$ $0,05)$

3. Kriteria pengujian

HO diterima bila t-tabel $<$ t-hitung $<$ t-tabel $\mathrm{HO}$ ditolak bila $t$ hitung $>$ t-tabel atau $\mathrm{t}$ hitung $<$ t-tabel

4. Perhitungan nilai $\dagger$ Dimana: 
Iman, et al/Jurnal Ekonomi Syariah Teori dan Terapan Vol. 6 No. 1 Januari 2019: 170-187; PENGARUH MOTIVASI KERJA ISLAM DAN BUDAYA KERJA ISLAM TERHADAP PRODUKTIFITAS KERJA KARYAWAN BMT DI GERBANGKERTASUSILA

$B=$ koefisien regresi dari variabel tingkat pendidikan

$\mathrm{Sbl}=$ standar error koefisien regresi

5. Kesimpulan

Dengan membandingkan t-hitung dengan t-tabel dapat diketahui pengaruh antara motivasi kerja Islam dan budaya kerja Islam terhadap produktivitas kerja karyawan.

\section{Uji F (Simultan)}

Apapun kriteria pengujiaannya adalah sebagai berikut:

1. $\mathrm{HO}: \beta 1=\beta 2=0$ artinya bahwa tingkat motivasi kerja Islam dan budaya kerja Islam secara bersama-sama tidak mempunyai pengaruh yang signifikan terhadap produktivitas kerja.

2. $\mathrm{Hl}: \beta 1 \neq \beta 2 \neq \beta 0$ artinya bahwa tingkat motivasi kerja Islam dan budaya kerja Islam secara bersama-sama mempunyai pengaruh yang signifikan terhadap produktivitas kerja.

3. Menentukan level of signifikan $a=0,05$

4. Kriteria yang digunakan dalam pengujian ini adalah sebagai berikut:

$\mathrm{Ho}=$ diterima apabila F-hitung $\leq$ F-tabel

$\mathrm{Ho}=$ ditolak apabila F-hitung > F-tabel

5. Kesimpulan

Dengan membandingkan $\mathrm{F}$ hitung dan $\mathrm{F}$ tabel diketahui pengaruh tingkat motivasi kerja Islam dan budaya kerja Islam terhadap produktivitas kerja.

\section{Koefisien Determinasi}

Koefisien determinasi (R2) pada intinya mengukur seberapa jauh kemampuan model dalam menerangkan variasi variabel dependen. Nilai koefisien determinasi adalah di antara nol dan satu. Nilai R2 yang kecil berarti kemampuan variabel-variabel independen menjelaskan variasi variabel dependen amat terbatas. Nilai yang mendekati satu berarti variabel-variabel independen memberikan hampir semua informasi yang dibutuhkan untuk memprediksi variasi variabel independen. Untuk menjelaskan aplikasi dengan menggunakan program SPSS.

\section{HASIL DAN PEMBAHASAN \\ Populasi Dan SampelhPada} penelitian ini, unit analisis yang digunakan adalah Usaha Kecil Menengah Sentra yang berada di Kabupaten/ kota Gerbangkertosusila. Berdasarkan data dari Dinas Koperasi dan UMKM Kabupaten /Kota Gerbangkertasusila Tahun 2015, jumlah BMT yang berhasil diidentifikasi sebanyak 200 unit usaha.

Jumlah UKM sentra dan jenis produk yang dihasilkan sebagaimana disajikan pada tabel 2.

Tabel 2.

Jumlah BMT di Kabupaten/kota Gerbangkertasusila

\begin{tabular}{|l|l|l|}
\hline No & Kota & $\begin{array}{l}\text { Jumlah } \\
\text { karyawan }\end{array}$ \\
\hline 1 & Gresik & 6 \\
\hline 2 & Bangkalan & 14 \\
\hline 3 & Mojokerto & 29 \\
\hline 4 & Surabaya & 47 \\
\hline 5 & Sidoarjo & 32 \\
\hline 6 & Lamongan & 72 \\
\hline & Total & 200 \\
\hline
\end{tabular}


Iman, et al/Jurnal Ekonomi Syariah Teori dan Terapan Vol. 6 No. 1 Januari 2019: 170-187; PENGARUH MOTIVASI KERJA ISLAM DAN BUDAYA KERJA ISLAM TERHADAP PRODUKTIFITAS KERJA KARYAWAN BMT DI GERBANGKERTASUSILA

Berdasarkan Tabel 2 diatas, maka jumlah populasi yang digunakan pada penelitian ini sebesar 200 unit usaha.

\section{Sampel}

Sampel pada penelitian ini ditentukan berdasarkan rumus dari Slovin (Husein Umar, 1997, hal. 59-60) dengan mengasumsikan populasi berdistribusi normal dan tingkat kesalahan pengambilan sampel sebesar $5 \%$. Secara matematis, rumus penentuan jumlah sampel penelitian adalah sebagai berikut

$$
\mathrm{n}=\frac{\mathrm{N}}{1+\mathrm{Ne}^{2}}
$$

Keterangan :

$\begin{array}{lll}\mathrm{n} & = & \text { Jumlah Sampel } \\ \mathrm{N} & =\text { Jumlah Populasi } & \\ \mathrm{e} & =\text { Persentase } & \text { kelonggaran }\end{array}$

ketidaktelitian (presisi) karena kesalahan pengambilan sampel yang masih dapat ditolelir.

Berdasarkan rumus diatas, maka jumlah sampel yang digunakan pada penelitian ini sebesar : 120 UKM.

$$
\begin{aligned}
& n=\frac{N}{1+N e^{2}} \\
& n=200:\left\{1+\left[200 \times(0,05)^{2}\right]\right\}=200
\end{aligned}
$$

\section{$: 1,6725=119,58$ dibulatkan 120}

Jumlah sampel yang digunakan sebesar 120 unit usaha. Pertimbangan yang digunakan dalam menentukan 120 unit usaha sebagai sampel penelitian untuk mengantisipasi tingkat pengembalian kuisioner yang disebarkan kepada responden agar memenuhi persyaratan jumlah minimum penggunaan alat analisis SEM. Pengambilan sampel dilakukan dengan metode probability sampling, dengan teknik Proportional Area Random Sampling, yaitu pengambilan sampel secara proporsional untuk masing-masing wilayah. Dasar penggunaan teknik ini adalah populasi tersebar ke dalam berbagai wilayah. Untuk menentukan jumlah sampel pada masing-masing wilayah, digunakan rumus sebagai berikut;

$$
n=\frac{X}{N} \times N 1
$$

Dimana:

$\mathrm{n}$ = Jumlah sampel yang diinginkan dari setiap wilayah

$\mathrm{N}$ = Jumlah seluruh populasi (BMT) yang berada di wilayah

$\mathrm{X}=$ Jumlah BMTsentra yang berada di masing-masing wilayah

$\mathrm{N} 1$ = Jumlah sampel yang digunakan dalam penelitia

Tabel 3.

Jumlah Sampel Penelitian

\begin{tabular}{|l|l|l|}
\hline No. & Kabupaten/Kota & $\begin{array}{l}\text { Jumlah } \\
\text { karyawan }\end{array}$ \\
\hline 1 & Gresik & 4 \\
\hline 2 & Bangkalan & 10 \\
\hline 3 & Mojokerto & 20 \\
\hline 4 & Surabaya & 32 \\
\hline 5 & Sidoarjo & 25 \\
\hline 6 & Lamongan & 61 \\
\hline & Total & 120 \\
\hline
\end{tabular}

\section{Metode Pengumpulan Data}

Penelitian ini menggunakan data primer dan data sekunder. Data primer dikumpulkan melalui penyebaran kuesioner kepada responden, yaitu 
Iman, et al/Jurnal Ekonomi Syariah Teori dan Terapan Vol. 6 No. 1 Januari 2019: 170-187; PENGARUH MOTIVASI KERJA ISLAM DAN BUDAYA KERJA ISLAM TERHADAP PRODUKTIFITAS KERJA KARYAWAN BMT DI GERBANGKERTASUSILA

perusahaan BMT melalui pemilik atau manajer, Karyawan dari BMT, dengan berdasarkan pada instrumen penelitian. Kuesioner digunakan untuk mengukur tentang Kinerja perusahaa dan kinerja usaha. Sedangkan data sekunder diperoleh melalui Dinas Koperasi \& UMKM , BPS, serta instansi terkait lainnya.

Uji Instrumen Penelitian Analisis Statistik Deskriptif Responden Terhadap Masingmasing Variabel

Analisis data merupakan proses penyederhanaan data ke dalam bentuk yang mudah dibaca, dipahami dan diinterpretasikan. Data yang akan dianalisis merupakan data hasil penelitian lapangan (field research) kemudian penulis melakukan analisis untuk menarik kesimpulan. Untuk menganalisis data digunakan metode statistik, karena metode statistik merupakan metode analisis data yang efektif dan efisien dalam suatu penelitian. Metode statistik yang digunakan adalah metode yang relevan yang penelitian yang dilakukan. Untuk menilai variabel, dan Y maka analisis yang digunakan berdasarkan ratarata (mean) daring masing-masing variabel. Nilai rata-rata (mean) didapat dengan cara menjumlahkan semua data dari setiap variabel, lalu dibagi dengan jumlah responden. Rumus nilai rata-rata (mean) yang dikemukakan oleh Sugiyono (2006:43) adalah sebagai berikut.

$$
M e=\frac{\sum X 1}{n}
$$

Keterangan :

$$
\begin{array}{ll}
\text { Me } & =\text { Mean (rata-rata) } \\
\sum X 1 & =\text { Jumlah Nilai } X \text { ke } 1 \text { sampai } \mathrm{n} \\
\mathrm{n} & =\text { Jumlah Individu }
\end{array}
$$

1. Hasil rata-rata setiap variabel dependen dan indepen (lihat lampiran)

a. Variable Motivasi kerja Islam (X1)

Diketahui : $\quad \sum X 1=2192$

$$
\begin{aligned}
& n=120 \\
& M e
\end{aligned}
$$

b. Variabel Budaya kerja Islam(X2)

Diketahui : $\quad \sum X 2=11308$

$n=120$

$$
M e=94,233
$$

c. Variabel Produktivitas kerja Karyawan BMT (Y)

Diketahui : $\quad \Sigma Y=2640$ $n=120$

$$
M e=22
$$

\section{Pengujian hasil/Skor rata-rata setiap}

\section{variable dengan skala interval}

Menurut Suharyadi dan Purwanto (2003), skala interval adalah suatu skala pemberian angka pada obyek yang mempunyai sifat ukuran ordinal, dan mempunyai jarak atau interval yang sama. Dalam penelitian ini interval kategori atau kelas interval ditentukan sebagai berikut :

Kelas interval $=$ Nilai terbesar - Nilai terkecil

4

Besarnya interval kelas mean setelah diketahui, kemudian dibuat rentang skala, sehingga dapat diketahui dimana letak rata-rata penilaian responden terhadap 
Iman, et al/Jurnal Ekonomi Syariah Teori dan Terapan Vol. 6 No. 1 Januari 2019: 170-187; PENGARUH MOTIVASI KERJA ISLAM DAN BUDAYA KERJA ISLAM TERHADAP PRODUKTIFITAS KERJA KARYAWAN BMT DI GERBANGKERTASUSILA

setiap variabel yang dipertanyakan.

Berikut adalah tabel yang memuat rentang skala mean yang dapat digunakan. Perhitungan kelas interval penelitian sebagai berikut :

Tabel 4.

Skor Jawaban Pertanyaan

\begin{tabular}{|c|c|c|c|}
\hline \multirow{2}{*}{ No } & \multirow{2}{*}{$\begin{array}{l}\text { JAWABAN } \\
\text { PERTANYAA } \\
\mathbf{N}\end{array}$} & \multicolumn{2}{|l|}{ Skor } \\
\hline & & $\begin{array}{l}\text { Pertanyaa } \\
\mathrm{n}(+)\end{array}$ & $\begin{array}{l}\text { Pertanyaa } \\
\text { n (-) }\end{array}$ \\
\hline 1. & $\begin{array}{l}\text { Sangat } \\
\text { Tidak Setuju } \\
\text { (STS) }\end{array}$ & 1 & 1 \\
\hline 2. & $\begin{array}{l}\text { Tidak Setuju } \\
\text { (TS) }\end{array}$ & 2 & 2 \\
\hline 3. & Setuju (S) & 3 & 3 \\
\hline 4. & $\begin{array}{l}\text { Sangat } \\
\text { Setuju (SS) }\end{array}$ & 4 & 4 \\
\hline
\end{tabular}

a. Skala interval variable Motivasi kerja Islam (X1)

Variabel independen yaitu Sistem motivasi kerja Islam, penulis mengambil nilai tertinggi yaitu 4 (empat) dan nilai terendah yaitu 1 (satu) dikalikan dengan banyaknya pertanyaan pada kuesioner dengan jumlah 6 (enam), lalu dikalian dengan jumlah responden sebanyak 120 ( seratus dua puluh ) orang.

$$
\begin{array}{ll}
\text { Nilai index terbesar } & =4 \times 6=24 \\
\text { Nilai index terkecil } & =1 \times 6=6 \\
\text { Jarak Interval } & =\frac{(24-6)}{4}=4,5
\end{array}
$$

TABEL 5.

KELAS INTERVAL (X1)

\begin{tabular}{|l|l|}
\hline Kriteria & Interval \\
\hline Sangat Rendah & $6-10,5$ \\
\hline Rendah & $10,6-15,1$ \\
\hline
\end{tabular}

\begin{tabular}{|l|l|}
\hline Kuat & $15,2-19,7$ \\
\hline Sangat kuat & $19,8-24$ \\
\hline
\end{tabular}

Diketahui $=\operatorname{Me}(X 1)=19,8$ dilihat dari hasil criteria kelas interval diatas maka dapat di simpulkan bahwa data tersebut memiliki skor yang kuat di dalam penelitian ini.

\section{b. Skala interval variable Budaya kerja Islam (X2)}

Variabel independen yaitu Sistem budaya kerja Islam, penulis mengambil nilai tertinggi yaitu 4 (empat) dan nilai terendah yaitu 1 (satu) dikalikan dengan banyaknya pertanyaan pada kuesioner dengan jumlah 30 (enam), lalu dikalian dengan jumlah responden sebanyak 120 ( seratus dua puluh ) orang.

$$
\begin{array}{ll}
\text { Nilai index terbesar } & =4 \times 30=120 \\
\text { Nilai index terkecil } & =1 \times 30=30 \\
\text { Jarak Interval } & =\frac{(120-30)}{4}=22,5
\end{array}
$$

TABEL 6.

KELAS INTERVAL (X2)

\begin{tabular}{|l|l|}
\hline Kriteria & Interval \\
\hline Sangat Rendah & $30-52,5$ \\
\hline Rendah & $52,6-75,1$ \\
\hline Kuat & $75,2-97,7$ \\
\hline Sangat kuat & $97,8-120$ \\
\hline
\end{tabular}

Diketahui $=\operatorname{Me}(X 2)=94,23$ dilihat dari hasil criteria kelas interval diatas maka dapat di simpulkan bahwa data tersebut memiliki skor yang kuat di dalam penelitian ini.

\section{c. Skala interval variable Produktivitas kerja ( $(Y)$}

Variabel independen yaitu Sistem motivasi kerja Islam, penulis mengambil 
Iman, et al/Jurnal Ekonomi Syariah Teori dan Terapan Vol. 6 No. 1 Januari 2019: 170-187; PENGARUH MOTIVASI KERJA ISLAM DAN BUDAYA KERJA ISLAM TERHADAP PRODUKTIFITAS KERJA KARYAWAN BMT DI GERBANGKERTASUSILA

nilai tertinggi yaitu 4 (empat) dan nilai terendah yaitu 1 (satu) dikalikan dengan banyaknya pertanyaan pada kuesioner dengan jumlah 7 (tujuh), lalu dikalian dengan jumlah responden sebanyak 120 ( seratus dua puluh ) orang.

$$
\begin{array}{ll}
\text { Nilai index terbesar } & =4 \times 7=28 \\
\text { Nilai index terkecil } & =1 \times 7=7 \\
\text { Jarak Interval } & =\frac{(28-7)}{4}=5,25
\end{array}
$$

TABEL 7.

KELAS INTERV AL (Y)

\begin{tabular}{|l|l|}
\hline Kriteria & Interval \\
\hline Sangat Rendah & $7-12,25$ \\
\hline Rendah & $12,26-17,51$ \\
\hline Kuat & $17,52-22,77$ \\
\hline Sangat kuat & $22,77-28$ \\
\hline
\end{tabular}

Diketahui $=\operatorname{Me}(Y)=22$ dilihat dari hasil criteria kelas interval diatas maka dapat di simpulkan bahwa data tersebut memiliki skor yang kuat di dalam penelitian ini.

\section{Uji Kualitas Data}

\section{Uji Validitas dan Uji Normalitas}

Validitas adalah suatu derajat ketepatan alat ukur penelitian tentang isi sebenarnya yang diukur. Analisis validitas item bertujuan untuk menguji apakah tiap butir pertanyaan benar-benar telah sahih, paling tidak dapat menetapkan derajat yang tinggi dari kedekatan data yang diperoleh dengan apa yang diyakini dalam pengukuran. Pengukuran dilakukan dengan cara mengkorelasikan antar skor item dengan skor total item. Dalam hal ini koefisien korelasi yang dinilai signifikansinya lebih kecil dari $5 \%$ menunjukkan bahwa item-item yang sudah sahih sebagai pembentuk indikator.
Validitas merupakan ketepatan dan kecermatan suatu alat ukur dalam melakukan fungsi ukurnya (Umar, 1997: 58). Alat ukur validitas yang tinggi berarti mempunyai varian kesalahan yang kecil, sehingga memberikan keyakinan bahwa data yang terkumpul merupakan data yang dapat dipercaya. Instrumen penelitian memiliki validitas tinggi mengarah hasil penelitian mampu menjelaskan masalah penelitian sesuai dengan kejadian sebenarnya.

Pengujian validitas dilakukan dengan cara mengkorelasikan skor masing-masing butir pertanyaan dengan skor total sebagai hasil penjumlahan semua skor butir pertanyaan dengan menggunakan teknik korelasi bivariate pearson. Untuk mengetahui apakah suatu butir pertanyaan sudah dianggap valid, maka akan dilihat nilai dari koefisien validitas dibandingkan dengan nilai probabilitas. Interpretasi koefisien validitas dianggap valid apabila koefisien korelasi $>0.2343$ ( $\mathrm{df}=118$ ) sehingga butir - butir tersebut dianggap valid, sebaliknya jika di dapatkan koefisien validitas kurang dari 0.2343 ( $d f=118$ ) maka butir - butir tersebut tidak valid.

Pengujian Normalitas dapat dilihat dari jika nila probabilitas $\left(R^{2}\right)$ kurang dari (<) 0,05 shingga dimensi dari setiap variabel dinyatakan terdistribusi normal, sebaliknya jika nilai probabilitas $\left(R^{2}\right)$ lebih besar dari (>) 0,05 dimensi setiap variabel dinyatakan tidak terdistribusi secara normal. Pengujian dapat dilihat di dalam tabel berikut: 
Iman, et al/Jurnal Ekonomi Syariah Teori dan Terapan Vol. 6 No. 1 Januari 2019: 170-187; PENGARUH MOTIVASI KERJA ISLAM DAN BUDAYA KERJA ISLAM TERHADAP PRODUKTIFITAS KERJA KARYAWAN BMT DI GERBANGKERTASUSILA

Validitas adalah suatu derajat ketepatan alat ukur penelitian tentang isi sebenarnya yang diukur. Analisis validitas item bertujuan untuk menguji apakah tiap butir pertanyaan benar-benar telah sahih, paling tidak dapat menetapkan derajat yang tinggi dari kedekatan data yang diperoleh dengan apa yang diyakini dalam pengukuran. Pengukuran dilakukan dengan cara mengkorelasikan antar skor item dengan skor total item. Dalam hal ini koefisien korelasi yang dinilai signifikansinya lebih kecil dari $5 \%$ menunjukkan bahwa item-item yang sudah sahih sebagai pembentuk indikator. Validitas merupakan ketepatan dan kecermatan suatu alat ukur dalam melakukan fungsi ukurnya (Umar, 1997: 58). Alat ukur validitas yang tinggi berarti mempunyai varian kesalahan yang kecil, sehingga memberikan keyakinan bahwa data yang terkumpul merupakan data yang dapat dipercaya. Instrumen penelitian memiliki validitas tinggi mengarah hasil penelitian mampu menjelaskan masalah penelitian sesuai dengan kejadian sebenarnya.

Pengujian validitas dilakukan dengan cara mengkorelasikan skor masing-masing butir pertanyaan dengan skor total sebagai hasil penjumlahan semua skor butir pertanyaan dengan menggunakan teknik korelasi bivariate pearson. Untuk mengetahui apakah suatu butir pertanyaan sudah dianggap valid, maka akan dilihat nilai dari koefisien validitas dibandingkan dengan nilai probabilitas. Interpretasi koefisien validitas dianggap valid apabila koefisien korelasi $>0.2343$ ( $\mathrm{df}=118$ ) sehingga butir - butir tersebut dianggap valid, sebaliknya jika di dapatkan koefisien validitas kurang dari 0.2343 ( $d f=118$ ) maka butir - butir tersebut tidak valid.

\section{Uji Reliabilitas}

Reliabilitas adalah derajat ketepatan, ketelitian atau keakuratan yang ditunjukkan oleh instrumen pengukuran (Umar, 1997: 57). Dengan demikian, uji reliabilitas bertujuan untuk mengukur ukuran internal consistency indikator suatu variabel. Suatu kuesioner dapat dikatakan reliabel atau handal jika jawaban seseorang terhadap pertanyaan adalah konsisten atau stabil (Gozhali, 2006). Instrumen penelitian dikatakan reliabel jika nilai Cronbach Alpha > 0,60 (Nunnally, 1967 dalam Gozhali 2006).

Reliabilitas adalah cara untuk menguji sejauh mana hasil suatu pengukuran dapat dipercaya. Alat ukur dikatakan memiliki realibilitas yang tinggi jika dalam beberapa kali pelaksanaan pengukuran terhadap kelompok subjek yang sama deperoleh hasil yang relative sama. Validitas adalah suatu derajat ketepatan alat ukur penelitian tentang isi sebenarnya yang diukur. Analisis validitas item bertujuan untuk menguji apakah tiap butir pertanyaan benar-benar telah sahih, paling tidak dapat menetapkan derajat yang tinggi dari kedekatan data yang diperoleh dengan apa yang diyakini dalam pengukuran. Pengukuran dilakukan dengan cara mengkorelasikan antar skor item dengan skor total item. Dalam hal ini 
Iman, et al/Jurnal Ekonomi Syariah Teori dan Terapan Vol. 6 No. 1 Januari 2019: 170-187; PENGARUH MOTIVASI KERJA ISLAM DAN BUDAYA KERJA ISLAM TERHADAP PRODUKTIFITAS KERJA KARYAWAN BMT DI GERBANGKERTASUSILA

koefisien korelasi yang dinilai signifikansinya lebih kecil dari $5 \%$ menunjukkan bahwa item-item yang sudah sahih sebagai pembentuk indikator.

Hasil uji validitas untuk pernyataan Persepsi Motivasi Kerja Islam jumlah itemnya sebanyak 2 butir, Niat baik dengan 3 butir pertanyaan dan Takwa Dalam Bekerja dengan 3 butir pertanyaan setelah diuji validitas internalnya (lihat lampiran 2), dengan korelasi product moment, diperoleh koefisien korelasi yang memuaskan untuk semua butir. dan nilai kecenderungan $P=0,000$ atau $<0,05$. Ini berarti untuk semua butir pernyataan dinilai valid.

Untuk pernyataan Persepsi Budaya Kerja Islam (X2) terhadap Produktivitas Kerja Islam dengan 10 butir budaya Islam dengan masing-masing pertanyaan sebanyak 3 butir, diperoleh koefisien korelasi yang memuaskan untuk semua butir dan nilai kecenderungan $P=0,000$ atau $<0,05$. Ini berarti untuk semua butir pernyataan dinilai valid.

$$
\text { Untuk }
$$

pernyataan

Produktivitas`Kerja Islam BMT sebanyak 10 butir, diperoleh koefisien korelasi yang memuaskan untuk semua butir dan nilai kecenderungan $P=0,000$ atau $<0,05$. Ini berarti untuk semua butir pernyataan dinilai valid.
Sehingga butir-butir instrumen untuk Persepsi Karyawan terhadap Motivasi Kerja Islam $\left(X_{1}\right)$ dengan enam butir pertanyaan aktivitas motivasi, Persepsi karyawan terhadap Budaya Kerja Islam $\left(X_{2}\right)$ dengan sepuluh butir pertanyaan Budaya Kerja Islam, dan Produktivitas Kerja Islam (Y) dengan tujuh butir pertanyaan aktivitas produktivitas dapat dikatakan valid.

\section{Analisis Model dan Pengujian Hipotesis}

\section{(Regresi Linier berganda)}

\subsubsection{Uji † (UJi Parsial)}

Tabel 8. Hasil Perhitungan Uji $\dagger$

\section{Coefficients(a) Uji †}

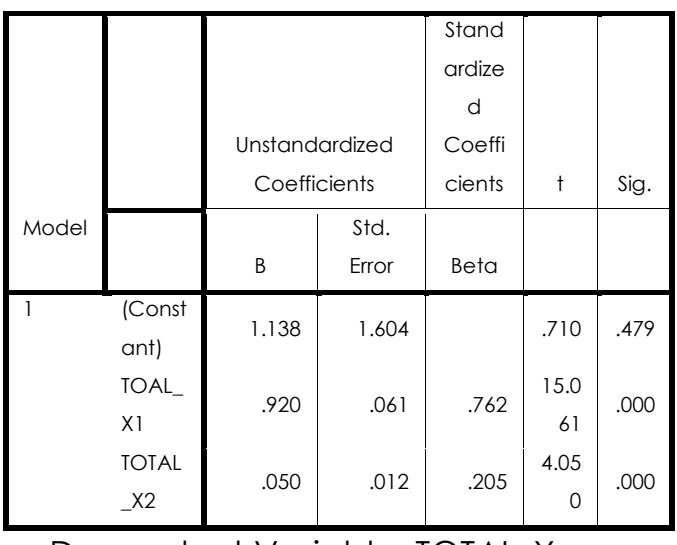

a Dependent Variable: TOTAL_Y

$\mathrm{HO}=\mathrm{X}$ tidak berpengaruh signifikan

terhadap $Y$

$\mathrm{H} \mathrm{l}=\mathrm{X}$ berpengaruh signifikan terhadap $\mathrm{Y}$

Pengambilan keputusan

1. HO diterima dan $\mathrm{Hl}$ ditolak jika nilai $\dagger$ hitung < † table / jika nilai signifikan > 0,05 ( tidak signifikan )

2. $\mathrm{HO}$ ditolak dan $\mathrm{HI}$ diterima jika nilai $\dagger$ hitung > † table / jika nilai signifikan < 0,05 ( signifikan )

$\dagger$ table $=0,05 / 2 ; 120-2-2=0,025 ; 116=$ 1,981 
[† hitung $X 1=15,061]>[\dagger$ table $=1,981] /$ nilai signifikan $\mathrm{X} 1=0,000<0,05$ ( Signifikan / $\mathrm{H} 0$ ditolak dan $\mathrm{H} 1$ diterima $)[t$ hitung $X 2=$ $4,050$ ] $>$ [ table $=1,981] /$ nilai signifikan $\mathrm{X} 1=0,000<0,05$ ( Signifikan / HO ditolak dan $\mathrm{HI}$ diterima |Dari hasil perhitungan SPSS diatas, Maka dapat ditarik kesimpulan hasil sebagai berikut :

1. Variabel Motivasi Kerja Islam (X1) memiliki hasil bahwa $\dagger$ hitung $=$ 15,061 lebih besar dari $(>)$ t tabel $(0,025 ; 116)=1,981 /$ nilai sig $X 1$ $=0,000$ lebih kecil (<) 0,05, maka variabel Motivasi kerja Islam (X1) dapat dinyatakan berpengaruh secara signifikan terhadap Variabel Produktivitas kerja karyawan BMT (Y)

2. Variabel Budaya Kerja Islam (X2) memiliki hasil bahwa $\dagger$ hitung $=$ 4,050 lebih besar dari (>) † tabel $(0,025 ; 116)=1,981$ /nilai sig $\times 2=$ 0,00 lebih kecil (<) 0,05, maka variabel budaya kerja Islam (X2) dapat dinyatakan berpengaruh secara signifikan terhadap Variabel Produktivitsa Kerja Karyawan BMT $(Y)$.

\section{Uji F (Simultan)}

Tabel 9.

Hasil Perhitungan Uji F ANOVA(b)

\begin{tabular}{|c|c|c|c|c|c|c|}
\hline $\begin{array}{l}\text { Mo } \\
\text { del }\end{array}$ & & $\begin{array}{l}\text { Sum of } \\
\text { Squares }\end{array}$ & $d f$ & $\begin{array}{l}\text { Me } \\
\text { an } \\
\text { Sa } \\
\text { var } \\
\mathrm{e}\end{array}$ & $\mathrm{F}$ & $\begin{array}{l}s \\
i \\
g\end{array}$ \\
\hline 1 & $\begin{array}{l}\text { Regres } \\
\text { sion } \\
\text { Residu } \\
\text { al } \\
\text { Total }\end{array}$ & $\begin{array}{r}2082.736 \\
452.564 \\
2535.300\end{array}$ & $\begin{array}{r}11 \\
7 \\
11 \\
9\end{array}$ & $\begin{array}{r}10 \\
41 . \\
36 \\
8 \\
\\
3.8 \\
68\end{array}$ & $\begin{array}{l}2 \\
6 \\
9\end{array}$ & $\begin{array}{l}0 \\
0 \\
0 \\
1 \\
a \\
1\end{array}$ \\
\hline
\end{tabular}

a Predictors: (Constant), TOAL_X1,

TOTAL_X2

b Dependent Variable: TOTAL_Y

$k=2 n=120$

$(k ; n-2)=(2 ; 118) \quad$ distribusi

table $\mathrm{F}=3,07$

$F$ hitung $=269,222$

\section{Pembahasan Uji F}

$\mathrm{F}$ hitung $>\mathrm{F}$ table $=$ variable $\mathrm{X} 1$ dan $\mathrm{X} 2$ (variabel bebas) berpengaruh (secara simultan) terhadap variable Y (variable terikat).

Dari data hasil Uji $F$ diatas dapat disimpulkan bahwa $\mathrm{F}$ hitung $=269,22$ lebih besar dari $\mathrm{F}$ tabel $(2 ; 188)=3,07$, jadi variabel motivasi kerja Islam (X1) dan variabel budaya kerja Islam (X2) berpengaruh signifikan terhadap variabel produktivitas kerja karyawan BMT (Y).

\section{Koefisien Determinasi}

Tabel 10.

Uji koef.Determinasi Model Summary

\begin{tabular}{|c|c|c|c|c|c|c|c|c|c|}
\hline \multirow{2}{*}{$\begin{array}{c}\text { Mod } \\
\text { el }\end{array}$} & \multirow[t]{2}{*}{$\mathrm{R}$} & \multirow{2}{*}{$\begin{array}{c}\mathrm{R} \\
\text { Squ } \\
\text { are }\end{array}$} & \multirow{2}{*}{$\begin{array}{l}\text { Adjusted R } \\
\text { Square }\end{array}$} & \multirow{2}{*}{$\begin{array}{l}\text { Std. Error } \\
\text { of the } \\
\text { Estimate }\end{array}$} & \multicolumn{5}{|c|}{ Change Statistics } \\
\hline & & & & & $\begin{array}{l}\text { R Square } \\
\text { Change }\end{array}$ & $\begin{array}{c}\mathrm{F} \\
\text { Chang } \\
\mathrm{e}\end{array}$ & df 1 & df2 & $\begin{array}{c}\text { Sig. F } \\
\text { Chang } \\
\mathrm{e}\end{array}$ \\
\hline 1 & $\begin{array}{l}.9061 \\
\text { a) }\end{array}$ & .821 & .818 & 1.967 & .821 & 269.222 & 2 & 117 & .000 \\
\hline
\end{tabular}

a Predictors: (Constant), TOAL_XI,

TOTAL_X2

Koef. Determinasi $(\mathrm{R}$ Square $)=0,821=$ $82,1 \%$

\section{Pembahasan Uji koefisien Determinasi}

Angka diatas mengandung arti bahwa motivasi kerja islam dan budaya kerja islam berpengaruh terhadap produktivitas kerja islam sbesar $82,1 \%$ sedangkan 
Iman, et al/Jurnal Ekonomi Syariah Teori dan Terapan Vol. 6 No. 1 Januari 2019: 170-187; PENGARUH MOTIVASI KERJA ISLAM DAN BUDAYA KERJA ISLAM TERHADAP PRODUKTIFITAS KERJA KARYAWAN BMT DI GERBANGKERTASUSILA

sisahnya $(100 \%-82,1 \%=17,9)$ dipengaruhi oleh variable lain diluar model regresi ini.

\section{DAFTAR PUSTAKA}

Departemen Agama Rl, Al-Quran Terjemah (Jakarta : CV Darus Sunnah,2002)

Afzalurahman, Muhammad Sebagai Seorang Pedagang, (Jakarta : Yayasan Swarna Bhumy, 1997)

Alma, Buchari dan Donni Juni Priansa, S.Pd, manajemen bisnis syari'ah, Bamdung: Alfabeta, 2009.

Cahyono, Bambang Tri, Manajemen Sumber Daya Manusia, Jakarta: Badan Penerbit IPWI, 1996.

Creswell, John W., 2003, Research Design ; Qualitative, Quantitative, And Mixed Methods Approaches, Second Edition, Sage Publications, Inc., New Delhi, India.

Darwan Rahardjo, Muhamad Islam dan Transformasi Sosial-Ekonomi, Yogyakarta: LSAF, 1999.

Djazuli, Ahmad, 2002. Implementasi Kemaslahatan Umat dalam Rambu Rambu.

Didin Hafidhuddin dan Hendri Tanjung, Manajemen Syariah dalam Praktik, (Jakarta: Gema Insani Press, 2003).
Ghozali, Imam, 2005, Aplikasi Analisis Multivariate dengan Program SPSS, Badan Penerbit Universitas Diponegoro, Semarang.

Hasibuan, Malayu S.P., 1996, Manajemen Dasar, Pengertian dan Masalah, Edisi Kedua, Jakarta: PT Toko Gunung Agung.

Karim, Adi Warman, Ekonomi Islam, Jakarta: Gema Insani Press,2001

Mursi,Abdul Hamid, 1997. SDM yang Produktif Pendekatan Al-Quran dan Sains, Jakarta: Gema Insani Press 1997.

Muhammad Ismail Yusanto dan Muhammad Karebet Widjajakusuma, Menggagas Bisnis Islami, (Jakarta: Gema Insani Press, 2002).

Munir Sukoco, Badri, Manajemen Administrasi Perkantoran Modern. Surabaya: Erlangga, 2007.

Qardhawi, Yusuf, Norma dan Etika Ekonomi Islam, Jakarta:Gema Insani Press, 1997.

Roliyah, Ummi, Pendekatan Postmoderns Dalam Penelitian IImu Sosial Dan Budaya, Tidak Dipublikasikan

Sujudi Ragil Putra, Pengaruh Motivasi Kerja, Lingkungan Kerja dan 
Iman, et al/Jurnal Ekonomi Syariah Teori dan Terapan Vol. 6 No. 1 Januari 2019: 170-187; PENGARUH

MOTIVASI KERJA ISLAM DAN BUDAYA KERJA ISLAM TERHADAP PRODUKTIFITAS KERJA KARYAWAN BMT DI

GERBANGKERTASUSILA

Pengawasan Kerja Terhadap

Produktivitas Kerja Karyawan Pada

BMT Binal hsanul Fitri Yogyakarta,

Skripsi, Prodi Ekonomi UII

Yogyakarta, 2006

Syafii Antonio, Muhamad dan Tim Tazkia,

Ensiklopedia Leadership \&

Manajemen Muhammad SAW

"The Super Leader Super Manager" buku 2, Bisnis dan

Kewirausahaan, (Jakarta : Tazkia

Publishing, 2012)

Triguna, 1995, Budaya Kerja, Jakarta: Gunung Agung, 1995.

Tasmara, Toto,2002, membudayakan etos kerja Islami, Jakarta: gema insani press, 2002.

Sugiyono, 1999, Statistika Untuk Penelitian,

Cetakan Kedua, CV Alfabeta, Bandung

Saleh, Akh. Muwafik. 2009. Bekerja dengan Hati Nurani. Jakarta: Erlangga.
Sugiyono, 2009, Metode Penelitian Kuantitatif, Kualitatif dan R\&D, Bandung : Alfabeta.

Sinungan, Muchdarsyah.

(2003).

Produktivitas apa dan Bagaimana. Jakarta: Bumi Aksara.

Umar, Husein "Studi Kelayakan Bisnis", PT. Gramedia Pustaka Utama, Jakarta, 1997.

Umar, Husein, 2004, Metode Penelitian Untuk Skripsi Dan Tesis Bisnis, Cetakan Keempat, PT. Raja Grafindo Persada, Jakarta Ghozali, Imam, 2005, Aplikasi Analisis Multivariate dengan Program SPSS, Badan Penerbit Universitas Diponegoro, Semarang. 